\title{
Metode Selimut Insulasi Panas untuk Pencegahan Penurunan Suhu Tubuh Bayi Tikus Putih
}

\author{
Diah Eka Nugraheni ${ }^{1}$, Elvi Destariyani ${ }^{2}$, Sri Sumiati $^{3}$ \\ ${ }^{1,2,3}$ Jurusan Kebidanan, Politeknik Kesehatan Bengkulu, Indonesia \\ Email: diah1234@gmail.com
}

\begin{abstract}
Blanket Method of Heat Insulation for Prevention of Decreasing Body Temperature in White Mouse Babies. The temperature decrease is caused by heat loss by conduction, convection, evaporation, and radiation. Various methods for preventing heat loss in newborns include the use of plastic bags. Nugraheni's research in 2016, the use of plastic wrap in newborns can still result in body heat loss because polyethylene plastic is not heated insulation. Aluminum foil is one of the ingredients that insulates heat insulation. The use of aluminum foil is widely used in various fields, for example as a food wrap to keep it warm and an emergency blanket for mountain climbers. This study aims to determine the comparison of the use of blanket heat insulation and plastic wrap in preventing the decrease in body temperature of babies of white rats. The type of research used was quasi-experimental (Quasi-Experiment) with the design of "post test only control group design". The sample in this study was 30 white rats which were calculated based on Federer's formula. There were no statistically significant difference in the 15 th minute $\mathrm{p}=0.221$, 30th minute $\mathrm{p}=0.65$ and 30 th minute $\mathrm{p}=0.08$, this was due to the small number of samples studied but in a systematic way, the control group's median difference was -0.1 , then there was no significant difference in temperature change at 15 minutes in the blanket and plastic wrap group. In the 30 th minute, the median difference in the control group was -0.5 , so clinically there were differences in the blanket group and the plastic wrap group with a median difference of 0.0. In the 60th minute, the median difference in the control group was -1.2 , clinically there were differences in the blanket group and the plastic wrap group with a median difference of 1.9. There is a difference in the decrease in body temperature of baby white rats using the blanket method of heat insulation and plastic wrap.
\end{abstract}

Keywords: Decreased body temperature, Heat insulation blanket, Plastic wrap

\begin{abstract}
Abstrak: Metode Selimut Insulasi Panas untuk Pencegahan Penurunan Suhu Tubuh Bayi Tikus Putih. Penurunan suhu diakibatkan oleh kehilangan panas secara konduksi, konveksi, evaporasi dan radiasi. Berbagai metode pencegahan kehilangan panas pada bayi baru lahir diantaranya adalah penggunaan kantong plastik. Penelitian Nugraheni 2016, penggunaan plastic wrap pada bayi baru lahir masih dapat terjadi kehilangan panas tubuh, karena plastik polyethilene tidak bersifat insulasi panas. Alumunium foil merupakan salah satu bahan yang bersiat insulator panas. Penggunaan alumunium foil banyak digunakan dalam berbagai bidang contohnya sebagai pembungkus makanan agar tetap hangat dan selimut emergency bagi pendaki gunung. Penelitian ini bertujuan mengetahui perbandingan penggunaan selimut insulasi panas dan plastic wrap dalam pencegahan penurunan suhu tubuh bayi tikus putih. Jenis penelitian yang digunakan adalah eksperimen semu (Quasi Experiment) dengan rancangan "post test only control group design". Sampel Penelitian ini tikus putih sebanyak 30 ekor yang dihitung berdasarkan rumus Frederer. Secara statistik tidak terdapat perbedaan bermakna pada menit ke $15 p=0.221$, menit ke $30 p=0.65$ dan menit ke $30 p=0.08$, hal ini disebabkan jumlah sampel yang diteliti sedikit namun secara klinis, nilai selisih median kelompok kontrol adalah -0.1, maka tidak terdapat perbedaan bermakna perubahan suhu pada menit ke 15 pada kelompok selimut dan plastic wrap. Pada menit ke 30, selisih median kelompok kontrol adalah - 0.5 maka secara klinis terdapat perbedaan pada kelompok selimut dan kelompok plastic wrap dengan beda median 0.0. Pada menit ke 60, selisih median kelompok kontrol adalah -1.2 maka secara klinis terdapat perbedaan pada kelompok selimut dan kelompok plastic wrap dengan beda median 1.9. Terdapat perbedaan penurunan suhu tubuh bayi tikus putih dengan menggunakan metode selimut insulasi panas dan plastic wrap.
\end{abstract}

Kata kunci: Penurunan suhu tubuh, Selimut insulasi panas, Plastic wrap 


\section{PENDAHULUAN}

Kurang baiknya penanganan bayi baru lahir yang dapat mengakibatkan bayi mengalami cacat seumur hidup dan kematian. Misalnya sebagai akibat hipotermia pada bayi baru lahir dapat terjadi cold stress yang selanjutnya dapat menyebabkan hipoksemia atau hipoglikemia dan mengakibatkan kerusakan otak (Sarwono, 2007).

Kemampuan bayi yang belum sempurna dalam memproduksi panas maka bayi sangat rentan untuk mengalami hipotermia (Kliegman RM, 2012).

Bayi baru lahir kehilangan panas empat kali lebih besar dari pada orang dewasa, sehingga mengakibatkan terjadinya penurunan suhu. Bayi baru lahir mempunyai area permukaan besar terhadap masa dibanding orang dewasa $(0,066 \mathrm{~m} 2 / \mathrm{kg}$ untuk $3 \mathrm{~kg}$ bayi dibanding 0,025 $\mathrm{m} 2 / \mathrm{kg}$ untuk $70 \mathrm{~kg}$ dewasa), yang menyebabkan bayi baru lahir kehilangan panas lebih cepat (Davis, 1980 ). Bayi baru lahir juga mempunyai sedikit lemak untuk melindungi, $(16 \%$ berat badan dalam 3,5 kg bayi baru lahir dibanding 20$30 \%$ pada orang dewasa).

Pada 30 menit pertama bayi dapat mengalami penurunan suhu $3-4{ }^{\circ} \mathrm{C}$. Pada ruangan dengan suhu $20-25{ }^{\circ} \mathrm{C}$ suhu kulit bayi turun sekitar $0,3^{\circ} \mathrm{C}$ per menit.

Seorang bayi premature, lahir tanpa simpanan penuh jaringan lemak coklat yang menghambat produksi panas dalam lingkungan dingin, menyebabkan bayi beresiko (Davis, 1980). Secara khusus, jaringan lemak coklat berjumlah sekitar $2-5 \%$ berat badan neonatus (Astrup, 1986)

Neonatus full term mempunyai kemampuan menggigil dengan terbatas untuk menghasilkan panas, sedangkan bayi preterm tidak sama sekali. Selain itu, bayi preterm juga mempunyai respon vasomotor tidak stabil sehingga tidak dapat berkonstriksi secara adekuat untuk memperlambat kahilangan panas, serta mempunyai simpanan lemak coklat terbatas, sehingga tidak dapat menghasilkan panas dengan adekuat melalui jalur metabolik.

Prevalensi yang tinggi dari hipotermia telah dilaporkan secara luas bahkan dari negara tropis. WHO telah merekomendasikan asuhan untuk mempertahankan panas dalam asuhan bayi baru lahir, namun hipotermia terus berlanjut menjadi kondisi yang biasa terjadi pada neonatal, yang tidak diketahui, tidak di dokumentasikan dan kurang memperoleh penanganan (Onalo R, 2013).

Pada tahun 2011 sebanyak 38,1\% penyebab bayi yang dirujuk ke RS Wahidin
Sudiro Husodo karena hipotermia (Ema Alasiry 2011). Penelitian yang dilakukan Laptook dkk terlihat bahwa setiap penurunan suhu tubuh $1^{\circ} \mathrm{C}$ saat masuk rawat rumah sakit akan meningkatkan angka kematian $28 \%$ dan angka kejadian sepsis awitan lambat $11 \%$ (Laptook AR, 2007).

Berbagai metode pencegahan kehilangan panas pada bayi baru lahir diantaranya adalah penggunaan kantong plastik dan metode Inisiasi menyusu dini yang dinyatakan dapat mengurangi kehilangan panas pada bayi baru lahir. Bayi premature kurang dari 29 minggu yang dibungkus dengan kantong plastic transparan memiliki risiko lebih kecil mengalami hipotermia setelah dilahirkan sebelum dipindahkan ke ruang NICU (Knobel et al, 2005).

Di Rumah Sakit M.Yunus Bengkulu pada tahun 2013 terdapat 808 bayi baru lahir, dimana 365 diantaranya adalah BBLR, tahun 2014 tedapat 837 persalinan dengan 195 BBLR. BBLR memiliki risiko tinggi untuk kehilangan panas setelah dilahirkan.

Penelitian Nugraheni dkk (2016) di RSMY menyatakan bahwa menggunakan metode wrapping dengan kantong plastik masih memungkinkan terjadinya kehilangan panas dikarenakan bahan plastik tidak bersifat insulasi terhadap panas dengan terjadinya penurunan suhu tubuh bayi pada menit ke 60 .

Insulasi termal (isolasi termal, isolasi panas) adalah metode atau proses yang digunakan untuk mengurangi laju perpindahan panas/kalor. Panas atau energi panas (kalor) bisa dipindahkan dengan cara konduksi, konveksi, dan radiasi atau ketika terjadi perubahan wujud. Insulasi termal dapat mencegah perpindahan panas secara konduksi, konveksi, dan radiasi.

Insulator digunakan untuk memperkecil perpindahan energi panas. Insulasi termal, hanya dibicarakan perpindahan panas secara konduksi, konveksi, dan radiasi. Aliran panas dapat dikendalikan dengan proses ini, tergantung pada sifat material yang dipergunakan. Bahan yang digunakan untuk mengurangi laju perpindahan panas itu disebut isolator atau insulator.

Bahan material yang dapat digunakan sebagai insulator salah satunya adalah alumunium foil. Alumunium foil banyak digunakan sebagai insulator pada berbagai bidang contohnya sebagai pembungkus burger atau makanan siap saji agar tetap hangat dan juga pada tas bekal tahan panas yang dapat digunakan untuk menjaga makanan tetap hangat. Alumunium foil dapat digunakan sebagai insulator pada selimut bayi untuk mengurangi penurunan panas tubuh/suhu bayi setelah lahir. 
Selimut insulasi panas dengan berbahan alumunium oil belum pernah dicobakan pada bayi baru lahir dan belum diketahui efektifitas dan keamanannya sehingga pada penelitian ini sampel yang digunakan adalah hewan percobaan tikus putih.

\section{METODE}

Jenis penelitian yang digunakan adalah eksperimen semu (Quasi Experiment) dengan rancangan "post test only control group design". Variabel independen penelitian ini adalah Metode plastic wrap dan metode Selimut Insulasi panas sedangkan variabel dependen adalah perubahan suhu.

Sampel dalam penelitian ini menggunakan 6 kelompok tikus berumur 8-9 hari, masing masing kelompok berjumlah 5 ekor mencit, dan dilakukan pengukuran pada menit ke 15, 30 dan 60. Sampel dipilih secara random dengan jumlah sampel sebanyak 30 bayi tikus. Cara kerja penelitian ini dimulai dengan membuat Selimut insulasi panas dengan menggunakan bahan alumunium foil sebagai lapisan insulator yang diletakkan ada lapisan bagian dalam, kemudian diisi dengan busa tipis setebal $1 \mathrm{~cm}$ sebagai lapisan padding dan lapisan sebelah luar menggunakan kain katun, selanjutnya seluruh lapisan dijahit menjadi satu dan diberi perekat, selanjutnya membuat plastic wrap dengan bahan plastic polyethylene dan ditempel perekat.

Bayi tikus putih diletakkan dalam kandang setelah diadaptasikan selama 3 hari di tempat penelitian. Kemudian bayi tikus putih sebanyak 30 ekor dikelompokkan menjadi 5 dengan cara acak, masing-masing kelompok terdiri atas 5 ekor yaitu K1, K2, K3, K4, K5 dan K6. Tiap-tiap bayi tikus putih sebelum diberi perlakuan diukur suhu sebelum dilakukan intervensi (U1). Selanjutnya dilakukan intervensi dengan metode selimut insulasi panas dan plastic warp selama 15 menit (U2), 30 menit (U3) dan 60 menit (U4) dilakukan pengukuran suhu untuk mencatat perubahan suhu tubuh. Analisis untuk menghitung rata rata suhu setelah perlakuan menggunakan Uji $\mathrm{T}$ tidak berpasangan. Data yang diperoleh dari penelitian dianalisis secara statistik dengan uji anova dan uji post hoc.

\section{HASIL}

Tabel 1. Rata-rata Suhu Tubuh Bayi Tikus Sebelum Perlakuan

\begin{tabular}{crrrrrr}
\hline Kelompok & $\begin{array}{c}\text { Kelompok } \\
\text { 15 menit }\end{array}$ & Mean & $\begin{array}{c}\text { Kelompok } \\
\text { 30 menit }\end{array}$ & Mean & $\begin{array}{c}\text { Kelompok } \\
\text { 60 menit }\end{array}$ & Mean \\
\hline \multirow{3}{*}{ Selimut insulasi } & 37.5 & & 37.6 & & 37.4 & \\
& 37.5 & & 37.5 & & 37.5 & \\
& 37.6 & 37.6 & 37.4 & 37.52 & 37.4 & 37.38 \\
& 37.8 & & 37.6 & & 37.3 & \\
& 37.6 & & 37.5 & 37.3 & \\
\hline \multirow{2}{*}{ Plastic Wrap } & 37.5 & & 37.6 & & 37.4 & \\
& 37.6 & & 37.5 & & 37.3 & \\
& 37.7 & 37.54 & 37.4 & 37.54 & 37.4 & 37.40 \\
& 37.3 & & 37.7 & & 37.5 & \\
\hline
\end{tabular}

Berdasarkan tabel 1 rata-rata suhu tubuh bayi tikus dalam rentang batas normal, dengan rata rata suhu terendah 37.3 pada kelompok kontrol 60 menit dan rata-rata tertinggi 37.6 pada kelompok kontrol 15 menit.

Tabel 2. Rata-rata Perubahan Suhu Tubuh Bayi Tikus setelah 15, 30 dan 60 menit Perlakuan

\begin{tabular}{|c|c|c|c|c|c|c|c|c|c|}
\hline Kelompok & T0\T15 & Mean & $p$ & T0\T30 & Mean & $p$ & T0\T60 & Mean & $p$ \\
\hline \multirow{5}{*}{$\begin{array}{l}\text { Selimut } \\
\text { insulasi }\end{array}$} & -0.1 & \multirow{5}{*}{-0.02} & \multirow{5}{*}{0.374} & 0.1 & \multirow{5}{*}{0.125} & \multirow{5}{*}{0.33} & 0.2 & \multirow{5}{*}{0.26} & \multirow{5}{*}{0.03} \\
\hline & 0 & & & 0.2 & & & 0.2 & & \\
\hline & 0 & & & 0.2 & & & 0.2 & & \\
\hline & 0 & & & 0 & & & 0.4 & & \\
\hline & 0 & & & 0.1 & & & 0.3 & & \\
\hline \multirow{5}{*}{$\begin{array}{l}\text { Plastic } \\
\text { Wrap }\end{array}$} & 0 & \multirow{5}{*}{-0.06} & \multirow{5}{*}{0.70} & 0.1 & \multirow{5}{*}{0.1} & \multirow{5}{*}{0.34} & 0.1 & \multirow{5}{*}{-0.06} & \multirow{5}{*}{0.30} \\
\hline & -0.1 & & & 0.2 & & & -0.1 & & \\
\hline & 0 & & & 0.2 & & & -0.1 & & \\
\hline & -0.1 & & & 0.1 & & & -0.2 & & \\
\hline & -0.1 & & & 0.1 & & & 0 & & \\
\hline
\end{tabular}


Pada menit ke 15 seluruh kelompok mengalami penurunan suhu tubuh dan penurunan terkecil terjadi pada kelompok selimut insulasi. Pada menit ke 30, kedua kelompok tidak terdapat perbedaan suhu tubuh. Pada menit ke 60 suhu tubuh pada kelompok selimut insulasi rata rata suhu tubuh naik $0.26(p=0.026)$.

Tabel 3. Perbandingan Perubahan Suhu Tubuh Bayi Tikus setelah Mendapatkan Perlakuan

\begin{tabular}{|c|c|c|c|c|c|c|c|}
\hline \multirow{2}{*}{ Perlakuan } & \multirow{2}{*}{$\mathbf{n}$} & \multicolumn{6}{|c|}{ Perubahan Suhu } \\
\hline & & 15' & & 30' & & $60^{\prime}$ & \\
\hline & & Median & $p$ & Median & $p$ & Median & $p$ \\
\hline Selimut & 5 & $0.0(-0.1-0.0)$ & 008 & $0.1(0.0-0.2)$ & $0 \Omega 6$ & $0.2(0.2-0.4)$ & ר 0 \\
\hline Plastik & 5 & $-0.1(-0.1-0.0)$ & 0.08 & $0.1(0.6-0.2)$ & 0.00 & $-0.1(-1.1-0.1)$ & 0.02 \\
\hline
\end{tabular}

Berdasarkan hasil tabel 3, pada perlakuan menit ke 60 terdapat perbedaan perubahan suhu tubuh bayi tikus. Selanjutnya dilakukan uji post hoc dengan uji Mann whitney untuk melihat perbandingan kelompok selimut insulasi dan plastic wrap. Secara statistik tidak terdapat perbedaan bermakna pada menit ke $15 p=0.221$, menit ke $30 p=0.65$ dan menit ke $60 p=0.08$, hal ini disebabkan jumlah sampel yang diteliti sedikit

Secara klinis, nilai selisih median adalah -0.1 , maka tidak terdapat perbedaan bermakna perubahan suhu pada menit ke 15 pada kelompok selimut dan plastic wrap. Pada menit ke 30 , selisih median adalah -0.5 maka secara klinis terdapat perbedaan pada kelompok selimut dan kelompok plastic wrap dengan beda median 0.1 . maka secara klinis terdapat perbedaan pada kelompok selimut dan kelompok plastic wrap dengan beda median 1.9.

\section{PEMBAHASAN}

Pada uji $\mathrm{T}$, secara statistik tidak terdapat perbedaan bermakna pada menit ke $15 \mathrm{p}=0.221$, menit ke $30 \mathrm{p}=0.65$ dan menit ke $30 \mathrm{p}=0.08$, hal ini disebabkan jumlah sampel yang diteliti sedikit namun secara klinis, nilai selisih median kelompok adalah -0.1, maka tidak terdapat perbedaan bermakna perubahan suhu pada menit ke 15 pada kelompok selimut dan plastic wrap. Pada menit ke 60, selisih median kelompok adalah -1.2 maka secara klinis terdapat perbedaan pada kelompok selimut dan kelompok plastic wrap dengan beda median 1.9.

Pada kelompok selimut insulasi, terjadi proses insulasi termal (isolasi termal, isolasi panas) yaitu metode atau proses yang digunakan untuk mengurangi laju perpindahan panas/kalor. Panas atau energi (kalor) bisa dipindahkan dengan cara konduksi, konveksi dan radiasi atau evaporasi (ketika terjadi perubahan wujud).

Aliran panas dapat dikendalikan dengan proses ini, tergantung pada sifat material yang dipergunakan. Panas dapat lolos meskipun ada upaya untuk menutupinya, tetapi isolator mengurangi panas yang lolos tersebut. Isolasi termal dapat menjaga wilayah tertutup seperti bangunan atau tubuh agar terasa hangat lebih lama dari yang sewajarnya, tetapi itu tidak mencegah hasil akhirnya, yaitu masuknya dingin dan keluarnya panas. Insulator digunakan untuk memperkecil perpindahan energi panas (Bergman, 2011).

Selimut insulasi yang digunakan dalam peneitian ini menggunakan insulator alumunium foil yang dapat mencegah perpindahan panas tubuh melalui konduksi, konveksi dan radiasi, selain itu pembuatan selimut yang dilapisi padding busa dan kain dapat mencegah terjadinya evaporasi. Hal ini yang dapat menjaga perubahan suhu pada bayi tikus.

Pada penelitian ini kelompok yang mendapat perlakuan plastic wrap juga tidak terjadi perubahan yang signifikan pada setiap kelompok waktu intervensi, hanya saja range perubahan suhunya lebih besar jika dibandingkan kelompok perlakuan selimut insulasi. Plastik yang digunakan dapat membantu mengurangi kehilangan panas karena dapat mencegah kehiangan panas melalui proses evaporasi.

Knobel et al., (2005) meneliti pengaruh penggunaan polyethelyne untuk membungkus bayi premature terhadap suhu tubuh Hasil penelitian ini menunjukan penggunaan polyethelyne merupakan faktor penting dalam mencegah kehilangan panas pada bayi premature. Knobel et al., (2005) meneliti tentang membungkus bayi premature pada ruang bersalin untuk mencegah terjadinya hipotermi dengan menggunakan kantong plastik,

Kehilangan cairan pada bayi berkorelasi berbanding terbalik dengan umur kehamilan karena bayi kurang bulan memiliki kulit yang tipis dan kehilangan cairan15 kali lebih besar pada bayi dengan umur kehamilan 25 minggu, dengan membungkus bayi menggunakan kantong plastik akan mencegah kehilangan panas dari penguapan. 


\section{SIMPULAN}

Penelitian menunjukkan bayi premature yang dibungkus dengan plastic sebelum dibawa ke ruangan NICU memiliki rata rata suhu tubuh yang lebih tinggi dibandingkan bayi premature dengan perawatan standar seperti segera mengeringkan tubuh bayi dengan kain, mengganti kain yang basah dan menutup kepala

\section{DAFTAR PUSTAKA}

Astrup, A. (1986). Thermogenesis in human brown adipose tissue and skeletal muscle induced by sympathomimetic stimulation. Acta Endocrinologica, 112(278): 1-32

Bergman, Lavine, Incropera and DeWitt. (2011). Introduction to Heat Transfer (sixth edition), Wiley.

Davis, V. (1980). The structure and function of brown adipose tissue in the neonate. JOGN Nurs. 9(6): 368- 72.

Ema Alasiry. (2011). Profil Bayi Rujukan Saat Masuk Rawat Ditinjau dari the STABLE Program. Sari Pediatri, Vol. 13, No. 4.

Kliegman RM. (2012). Janin dan bayi neonatus. Dalam: Ilmu Kesehatan Anak Nelson. Edisi ke-15, vol;1, Wahab AS, editor edisi bahasa Indonesia, hlm. 535-41. Jakarta: EGC.

Knobel, R. B., Wimmer Jr, J. E., \& Holbert, D. (2005). Heat loss prevention for preterm infants in the delivery room. Journal of Perinatology, 25(5), 304.

Knobel, R. B., Vohra, S., \& Lehmann, C. U. (2005). Heat loss prevention in the bayi dengan topi. Bayi premature kurang dari 29 minggu yang dibungkus dengan kantong plastic transparan memiliki risiko lebih kecil mengalami hipotermia setelah dilahirkan sebelum dipindahkan ke ruang NICU. Penelitian lain juga menunjukkan bahwa membungkus bayi premature kurang 34 minggu dengan menggunakan polyethylene plastic dapat menurunkan kejadian hipotermia.

delivery room for preterm infants: a national survey of newborn intensive care units. Journal of perinatology, 25(8), 514.

Laptook AR, Salhab W, Bhaskar B. (2007). Admission temperature of low birth weight infants and associated morbidities. Pediatrics, 119: 643-9.

Nugraheni, D. E., \& Heryati, K. (2019). Comparison Of IMD Method, Plastic Wrap, And Conventional Care On Prevention Of Reduction Of Body Temperature of New Baby. In 1st International Conference on InterProfessional Health Collaboration (ICIHC 2018). Atlantis Press.

Onalo R. (2013). Neonatal hypothermia in sub Saharan Africa: a review. Nigerian Journal of Clinical Practice, 16(2):129-38.

Sarwono. (2007). Ilmu Kebidanan. Jakarta: Yayasan Bina Pustaka Sarwono Prawiro Hardjo. 